\title{
VULNERABLE AREAS IN TOURIST CITIES OF COASTAL ZONES: CAMPECHE, MEXICO
}

\author{
BERTHA N. CABRERA SÁNCHEZ \& JOEL F. AUDEFROY \\ Instituto Politécnico Nacional, ESIA TEC, México
}

\begin{abstract}
The expansion of cities located in coastal areas, primarily the emergence of settlements on the periphery of Mexican tourist resorts, makes them increasingly vulnerable in physical and urban terms to a variety of natural phenomena (like extreme precipitation, tropical storms and hurricanes), which can cause disasters for local populations. The coastal zone of Campeche is $425 \mathrm{~km}$ long and in the last 30 years has undergone increasingly rapid growth of its population and the urban occupation of its coastline, increasing the number of people that might be affected by weather like hurricanes. This paper focuses on two central aspects: first, identifying vulnerable areas that are threatened by hydro-meteorological hazards; and second, identifying strategies for adapting to such risks, based on the experiences of affected communities. This information supports the hypothesis that empowerment and participation of the people, in conjunction with government strategies, can help reduce the risk of disaster and strengthen the inhabitants' resilience to hydro-meteorological hazards. We present a case study on the city of Campeche, in the state of Campeche, Mexico; a city popular among tourists, with highly valuable urban spaces rich in material, architectural, cultural and historical heritage. The process of urban growth reproduces and deepens inequalities, which directly affect the inhabitants' resilience against frequent natural phenomena; but a variety of urban, social, economic and political conditions should be taken into account in determining the strategies for surviving hydro-meteorological hazards.

Keywords: Campeche, coastal cities, Mexico, tourism, vulnerability, risk, marginalization, resilience, hydro-meteorological hazard, safety strategies, weather.
\end{abstract}

\section{INTRODUCTION}

Mexico is surrounded by coastline, of its 31 states, 17 have coastal regions. There are $7,828 \mathrm{~km}$ of coastline on the Pacific Ocean and the Gulf of California, while the Mexican states situated on the Gulf of Mexico and Caribbean have 3,294 km of coastline [1]. In the year 2015, approximately 18,683,124 Mexicans lived in coastal zones, belonging to 151 coastal municipalities: they represent $14.7 \%$ of the country's total population.

The state capital of Campeche, called San Francisco de Campeche (St. Francis of Campeche), has a tourist infrastructure consisting of 307 hotel establishments offering a total of 8,583 rooms, along with 661 restaurants, and 137 bars and nightclubs. The number of hotels has grown in the last five years from 299 (7,150 rooms) in 2012, to about 307 (8,583 rooms) in 2017, an increase of 34 hotels in a five-year period, according to the Mexican Ministry of Tourism (SECTUR) [2].

An area that is highly vulnerable to hydro-meteorological hazards, over the centuries there are records of hurricanes that have passed through the state causing flooding in urban localities close to the coasts, including the tourist zone of Campeche and neighboring areas. There were 31 hurricanes recorded in various documents dating from the year 1735 to 2018, and the number of tropical cyclones had risen in a very short period of time: since the year 1951, some years have seen two or even three such storms. The impact of flooding is recurrent in tourism, on the inhabitants and the government.

Because the city of San Francisco de Campeche is located in a coastal area that is directly exposed to weather events, it is important to identify the vulnerability and risk to which the 
inhabitants are exposed, due to the rapid growth of the population in recent years, and the consequent increase in occupancy of human settlements around the city.

The region's appeal to tourists generates poles of economic development for the population, which in turn increases demand in urban zones that require basic services like water, electricity, and sewage, as well as urban amenities and police presence, among others. But these elements have also contributed to the zone's vulnerability to hydro-meteorological events.

Historical statistical and geographic information regarding the hydro-meteorological hazards facing this population can be useful in developing strategies for adaptation and resilience, to reduce the risk of disaster and the potential loss of property in the affected areas.

\section{STUDY AREA AND METHODOLOGY}

\subsection{Study area}

The city of San Francisco de Campeche is located on the Yucatán peninsula, in eastern Mexico; it adjoins Guatemala to the south, Yucatán and Quintana Roo to the east, Tabasco to the west and the Gulf of Mexico to the north. It has considerable cultural, architectural and geographic heritage, but it is a region at constant risk of hydro-meteorological phenomena (Fig. 1).

The city's altitude ranges from $0-200 \mathrm{~m}$ above sea level, but is barely $1-10 \mathrm{~m}$ along the coast. The prevailing temperatures are between $26^{\circ} \mathrm{C}$ and $28^{\circ} \mathrm{C}$, and rainfall ranges from 1,000-12,000 mm. The soil types that predominate in the urban zones of Campeche, built

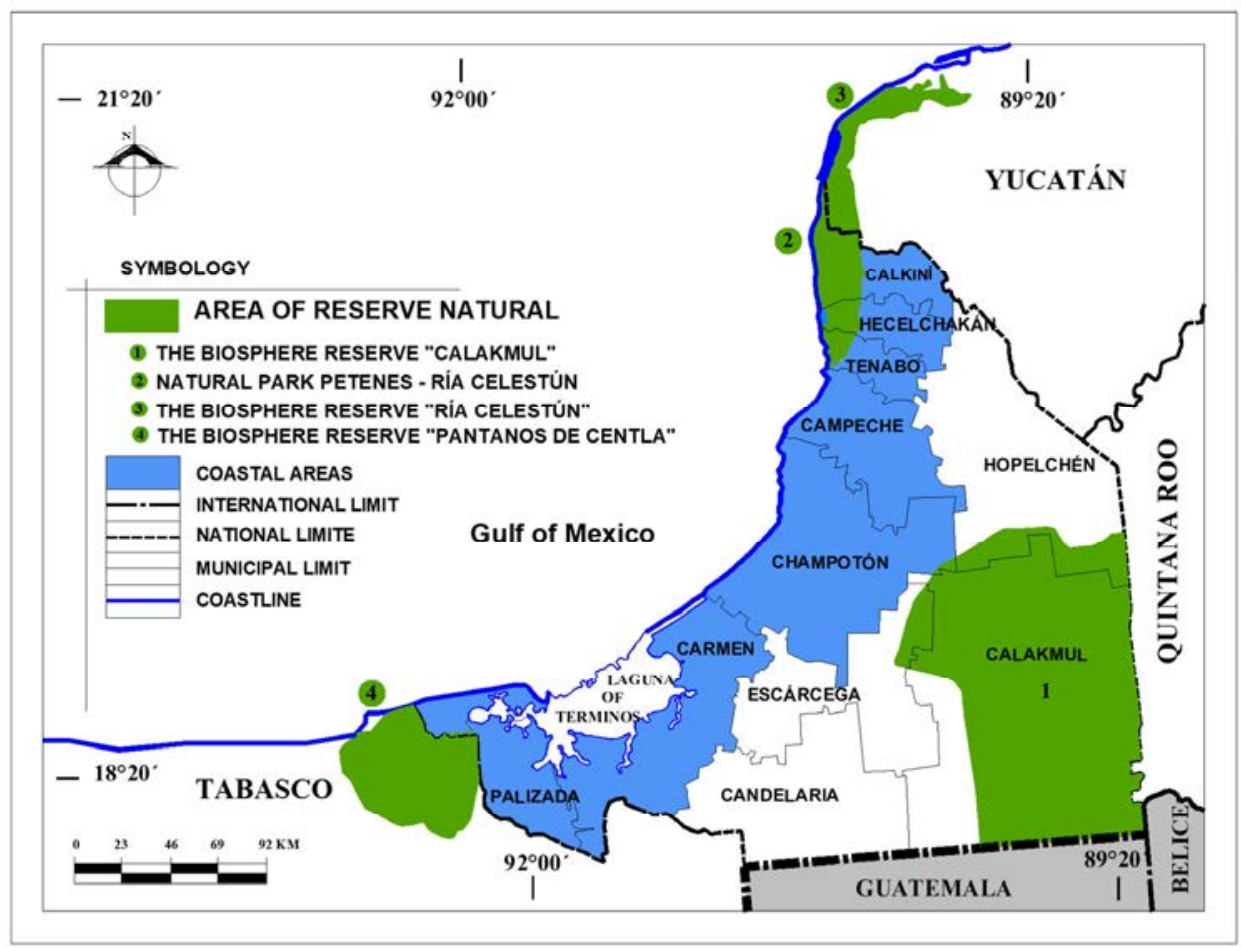

Figure 1: Location and municipal division, Campeche, México, 2019. 
primarily on low hills and beaches, are: Solonchaks, Vertisols and Phaeozems (characteristic of seaside coastal areas) [1].

In the year 2015, Campeche had a total of 899,931 inhabitants distributed in 11 municipalities, six of them coastal: Calkiní, Hecelchakán, Tenabo, Champotón, Carmen and Campeche. The largest of these are San Francisco de Campeche (sometimes called merely Campeche, like the state) and Ciudad del Carmen. The number of localities within the municipality of Campeche have risen from 85 in 1980 to 205 in 2010, a 141\% increase in just 30 years. Growth has been particularly pronounced in the urban areas along Campeche's coast, particularly in San Francisco de Campeche and Ciudad del Carmen (Table 1).

Table 1: Number of localities for each municipality in Campeche, Mexico, 1980-2010.

\begin{tabular}{|l|c|c|c|c|c|c|}
\hline Municipality & $\mathbf{1 9 8 0}$ & $\mathbf{1 9 9 0}$ & $\mathbf{1 9 9 5}$ & $\mathbf{2 0 0 0}$ & $\mathbf{2 0 0 5}$ & $\mathbf{2 0 1 0}$ \\
\hline Calkiní & 29 & 31 & 49 & 55 & 51 & $\mathbf{5 3}$ \\
\hline Campeche & 85 & 169 & 182 & 226 & 163 & $\mathbf{2 0 5}$ \\
\hline Carmen & 646 & 609 & 1,053 & 912 & 832 & $\mathbf{8 7 5}$ \\
\hline Champotón & 97 & 257 & 411 & 325 & 231 & $\mathbf{2 8 0}$ \\
\hline Hecelchakán & 11 & 20 & 218 & 22 & 24 & $\mathbf{2 5}$ \\
\hline Hopelchén & 101 & 225 & 181 & 115 & 103 & $\mathbf{1 2 2}$ \\
\hline Palizada & 174 & 311 & 19 & 185 & 157 & $\mathbf{1 5 2}$ \\
\hline Tenabo & 20 & 11 & 521 & 30 & 29 & $\mathbf{2 1}$ \\
\hline Eescárcega & & 317 & 29 & 270 & 223 & $\mathbf{2 3 4}$ \\
\hline Calakmul & & & & 187 & 159 & $\mathbf{1 5 8}$ \\
\hline Candelaria & & & & 772 & 651 & $\mathbf{6 5 3}$ \\
\hline
\end{tabular}

Campeche is considered an historic city, one of the few remaining examples in the Americas of a fortified/walled city. Within the old walled portion of the city, there are architectural vestiges dating from the 16th, 17th, 18th and 19th century, that are still in good condition [2], which stand as an historic testament for the city's inhabitants. The zone was classified as a World Heritage Site by the United Nations Educational Scientific and Cultural Organization (UNESCO) on 4 December 1999.

\section{METHODOLOGY}

This research was conducted on the basis of statistical and geographic data obtained from various government agencies, as well as through interviews with local inhabitants. The statistical data cover demographic, climatic and social aspects, and are superimposed on geographic representations for the purpose of analysis.

\subsection{Demographic, climatologic and social aspects}

The city of Campeche is one of the most popular tourist destinations in the state, and historic downtown San Francisco de Campeche is a UNESCO World Heritage Site; however, because of its geographic conditions, it is vulnerable to events like tropical depressions and storms, and the people living close to the coast are at frequent risk of flooding.

The demographic data collected (number of inhabitants, homes and localities) was used to develop a specific analysis of the current status of people leaving on the coast of San Francisco de Campeche, while data on the weather (temperature, precipitation and the number of hurricanes) is presented historically, given the importance of documenting 
references that show the historic memory of events that have had a negative impact on the areas' population and infrastructure. Social aspects were incorporated, to prepare an analysis of the reality faced by the communities that live along the coast; and thus, to identify the social vulnerability to which the population is exposed.

Geographic aspects are indispensable for identifying zones at risk of hydrometeorological events and to better detect and analyze their physical vulnerability in terms of population, housing, urban structures and weather. In this case, information was obtained primarily from government agencies like the Instituto Nacional de Estadística y Geografía (INEGI) (Mexican National Institute of Statistics and Geography) [1], Comité Nacional del Agua (CONAGUA) (National Water Committee) [4], Centro Nacional de Prevención de Desastres (CENAPRED) (National Center for Disaster Prevention) [5], and the US National Oceanic and Atmospheric Administration (NOAA) [6].

\section{CASE STUDY}

\subsection{Historical memory of hurricanes that have affected the city of Campeche}

Around $70 \%$ of the world's coastlines have experienced a rise in sea levels in an interval of $\pm 20 \%$ of the global average [7]. The Intergovernmental Panel on Climate Change (IPCC) report on the impacts of global warming mentions that coastal cities are exposed to flooding and changes in temperature, which result in damage and losses in means of subsistence, revenues, cultural identity and health in coastal communities (Table 2).

Table 2: Declared emergencies, disasters and weather-related emergencies 1735-2000, for the Municipality of Campeche, Mexico.

\begin{tabular}{|l|l|l|l|l|l|}
\hline Year & State & Event & Year & State & Event \\
\hline 1735 & $\begin{array}{l}\text { Veracruz, } \\
\text { Campeche }\end{array}$ & $\begin{array}{l}\text { Northerly storms, } \\
\text { thunder and lightning }\end{array}$ & 2002 & Campeche & Hurricane Isidore \\
\hline 1879 & Campeche & Crop losses & 2005 & Campeche & Hurricane Stan \\
\hline 1883 & $\begin{array}{l}\text { Campeche, } \\
\text { Yucatán }\end{array}$ & Strong gusts of wind & 2007 & Campeche & Hurricane Dean \\
\hline 1883 & $\begin{array}{l}\text { Campeche, } \\
\text { Yucatán }\end{array}$ & Crop losses & 2008 & Campeche & Hurricane Marco \\
\hline 1887 & Campeche & Hurricane & 2008 & Campeche & Hurricane Arthur \\
\hline 1888 & Campeche & Rains & 2010 & Carmen & Hurricane Richard \\
\hline 1889 & Campeche & Heavy hail, hurricane & 2010 & Campeche & Hurricane Karl \\
\hline 1898 & $\begin{array}{l}\text { Campeche: Río } \\
\text { Hampoli }\end{array}$ & Heavy rains & 2010 & Campeche & Hurricane Alex \\
\hline 1899 & Campeche & Heavy, severe rains & 2011 & Campeche & Hurricane Harvey \\
\hline 1973 & Nuevo Progreso & $\begin{array}{l}\text { Hurricane Brenda } 93 \\
\text { km/hr) }\end{array}$ & 2012 & Campeche & Hurricane Ernesto \\
\hline 1995 & Campeche & Hurricane Roxanne & 2012 & Campeche & Hurricane Helene \\
\hline 1995 & Campeche & $\begin{array}{l}\text { Hurricane Opal, winds } \\
\text { at 55 km/hr }\end{array}$ & 2013 & Campeche & Hurricane Barry \\
\hline 1996 & Campeche & Hurricane Dolly & 2014 & Campeche & Hurricane Dolly \\
\hline 1999 & Campeche & Hurricane Katrina & 2014 & Campeche & Hurricane Hanna \\
\hline 2000 & Campeche & Hurricane Keith & 2017 & Campeche & Hurricane Franklin \\
\hline 2001 & Campeche & Hurricane Chantal & - & - & - \\
\hline
\end{tabular}


In the year 1735, public records show flooding that damaged crops and property; between 1879 and 1899 there are a total of eight events recorded regarding hydro-meteorological hazard, among them hurricanes, hail, high tides and cyclones, which caused flooding whose most severe effects including loss of life, crops, livestock, canoes, infrastructure and access roads [8], [9].

Between 1973 and 2000, there were seven hurricanes on record: Brenda, Opal, Roxane, Dolly, Mitch, Katrina and Keith, and the heaviest damage was sustained by homes, infrastructure and urban facilities.

Between 2001 and 2014, there were 15 hurricanes, including Chantal (2001), Isidore (2002), Stan (2005), Dean (2007), Harvey (2011) and Barry (2013). Since the year 2001, the number of hydro-meteorological events has risen to two or three per year. There were two in 2008 (Marco and Arthur); three in 2010 (Alex, Karl and Richard); two in 2012 (Ernesto and Helene); and finally, two in 2014 (Dolly and Hanna) [10].

What is most striking in the data mentioned above is the frequency of recurrence and the intensity with which these extreme events have occurred in the city of Campeche. This coincides with the IPCC report, which shows that between 1993 and 2012, the Mexican Gulf Coast and Yucatán Peninsula have been hit by 233 extreme events related to hurricanes [7].

The population inhabiting the coastal zone of San Francisco de Campeche has risen steadily in the past 35 years, from 173,645 to 259,005 inhabitants, a population increase of $32.90 \%$. The largest increase in population has been in the municipalities of Carmen and San Francisco de Campeche. The number of homes in these areas has grown by $51.73 \%$ in the past 25 years; from 38,208 in 1990 to 79,159 in 2015, according to data from INEGI; and housing demand has continued to grow at a vigorous rate in recent years.

\subsection{Demographic aspects and social aspects of urban growth}

The most significant challenges Campeche faces in the area of urban habitat and mobility are irregular urban growth, de-population of the historic downtown due to service centralization, the concentration of employment in the central zone, creating efficient public transport, and the flooding in various parts of the city.

The Campeche State Sectorial Infrastructure and Urban Development Program mentions that the irregularly built areas of the state capital are located primarily on the outskirts of the urban area. The persistent presence of irregular human settlements in Campeche poses a challenge, not only because of the risks mentioned, but because it reduces the amount of land reserved for future growth. The swelling of the population in the past 40 years has created a steady demand for housing and need for urban facilities to satisfy the population.

Additionally, the displacement and occupation of mangrove areas makes the human communities occupying them vulnerable, and the coastal lagoons are jeopardized by the human communities that establish themselves on their shores.

\subsection{Social aspects and economic aspects}

Education is a determining factor in the capacity for adaptive response to disasters caused by hydro-meteorological phenomena [7].

The statistics on the degree of marginalization in the municipality are from the years 2005 and 2010, and they show an increased number of localities with a high degree of marginalization within that period, from 28 in 2005 to 34 in 2010, by which we found that San Francisco de Campeche has the third highest rate of marginalization in the entire state. 
Turning our attention to the number of localities in the municipality, this indicator rose from 85 in 1980 to 169 in 1990 (a 50.29\% increase), and then to 226 in 2000 (a $33.72 \%$ increase), yet then declined by $9.25 \%$ to 205 , in the year 2010 .

The pursuit of a balance between the economic activities that take place in coastal areas and tourist activities is a complex one, because both of these categories require services, and although they have a positive impact on job creation, they also have negative effects (rising population and demand for housing, hotel infrastructure, urban facilities and services). They also place their inhabitants in a position of risk and vulnerability to hydro-meteorological phenomena, because of the frequent occurrence of tropical storms and depressions.

Fishing, aquaculture, and tourism sustain coastal communities, which have been harmed and displaced by large-scale tourist development. In some coastal communities, this is because of the displacement of deep-rooted and ancestral means of subsistence; and in some cases, urban sprawl has transformed fishing communities into communities engaged in retail and tourism.

In analyzing the most important tourist zones of the state, the Mexican Ministry of Tourism considers Campeche to be the possessor of great cultural and historic wealth and stunning natural landscapes. The capital city of San Francisco de Campeche, which is also its largest city, is clearly appealing to tourists because of its historic downtown, neighborhoods, traditions and colonial architecture; but its geographic location makes its inhabitants vulnerable to the prevailing hydro-meteorological conditions.

The appeal of the city is not limited to visitors nor tourists: it is attractive also for local inhabitants, who seek job opportunities and the possibility of subsistence, qualities that it shares with any tourist-oriented city.

\subsection{Climate}

Changes in temperature and precipitation were obtained from statistics supplied by the National Weather Service [11], which was created to issue forecasts and alerts on the status of the weather. Temperatures in the municipality of Campeche have risen slightly. Over the past 35 years, the temperature has ranged from lows of $18.8^{\circ} \mathrm{C}$ to highs of $33.92^{\circ} \mathrm{C}$. Some of the repercussions of this rise in temperature directly affect the environment, because existing construction systems are no longer appropriate for the coastal zone. One of the immediate effects of the warmer weather was the demand for conventional systems to adjust temperatures in inhabitable spaces such as homes, hotels, offices, shopping centers and supermarkets; among others.

This increase in temperature is not limited to the state of Campeche: all of Mexico has seen temperatures rise to $6 \%$ above their historic average. It is estimated that $15 \%$ of the nation's territory, $68 \%$ of its population and $71 \%$ of its gross domestic product (GDP) is exposed to the adverse effects of climate change.

Precipitation has also risen, according to the same statistics. Over a 35-year period, the minimum rainfall was in the year 1986, when it was only $960 \mathrm{~mm}$; the maximum was recorded in the year 2005, at $1,790 \mathrm{~mm}$. There have been more bouts of heavy rain in recent years, resulting in flooding that affects most of the urban facilities close to the coastal areas, and most of Campeche's inhabitants suffer through this problem every year, along with the accompanying economic, social and health issues. The frequency of this type of hydrometeorological risk is becoming increasingly intense, causing greater damage to the population. Meteorologists project that temperatures and rainfall will continue rising in southern Mexico [7]. 
The nationwide economic damage resulting from climate events is estimated to grow from an annual average of 730 million pesos in 1980-1999, to 21.95 billion pesos in 2000-2012 [12]. At the same time, the population of Campeche has grown, and this, combined with climate change, has increased local exposure to hydro-meteorological hazards.

\subsection{Identification of hydro-meteorological hazards}

There have been various efforts on the part of government agencies to document and identify these hazards, including the Atlas of Natural Hazards of Campeche State [13] and the State Contingency Plan for Hydro-Meteorological Phenomena [14]. These present an overview of the primary hydro-meteorological phenomena that occur in the municipality of Campeche, addressing aspects such as: the presence of tropical cyclones and coastal flooding, rainy season projections and early alert systems for cyclones, all of which keeps the local inhabitants better informed of these forecasts. These documents contain very valuable information, but the main goal is to encourage preventive action by people living in coastal areas, who are frequently affected by these natural phenomena.

There are 11 municipalities in the state of Campeche. Seven of them are close to the coast: San Francisco de Campeche, Carmen, Champotón, Calkiní, Hecelchakán, Palizada and Tenabo. These localities are risk of hydro-meteorological phenomena. San Francisco de Campeche has 34 localities and 245,499 inhabitants that are affected by these phenomena, which is a total of $94.78 \%$ of its population [13] (Table 3).

Table 3: Localities at risk of hydro-meteorological phenomena, Campeche, 2014.

\begin{tabular}{|l|l|c|c|c|}
\hline Zone & Municipality & $\begin{array}{c}\text { Total } \\
\text { population }\end{array}$ & $\begin{array}{c}\text { Localities } \\
\text { at risk }\end{array}$ & $\begin{array}{c}\text { Total population } \\
\text { affected }\end{array}$ \\
\hline Coast & San Francisco de Campeche & 259,005 & 34 & 245,499 \\
\hline Coast & Carmen & 221,094 & 44 & 193,301 \\
\hline & Escárcega & 54,184 & 5 & 31,046 \\
\hline & Hopelchén & 37,777 & 18 & 22,404 \\
\hline & Candelaria & 41,194 & 11 & 14,498 \\
\hline Coast & Champotón & 83,021 & 18 & 13,284 \\
\hline Coast & Calkiní & 52,890 & 10 & 11,616 \\
\hline Coast & Hecelchakán & 28,306 & 6 & 10,931 \\
\hline & Calakmul & 26,882 & 9 & 6780 \\
\hline Coast & Palizada & 8352 & 12 & 2186 \\
\hline Coast & Tenabo & 8736 & 6 & 1914 \\
\hline
\end{tabular}

The State Contingency Plan for Hydro-Meteorological Phenomena mentions the following affected localities: Campeche, Chiná, Nohakal, Quetzal Edzná Modulo uno (Module 1), Quetzal Edzná Modulo dos (La libertad (Module 2)), Castamay, Chemblás, Bethania, San Camilo (Chencollí), Tikinmul, San Antonio Cayal, Crucero Oxá, Adolfo Ruíz Cortínez, Hobomó, Nuevo Pénjamo, Kikab, Melchor Ocampo, Bolonchén Cahuich, Tixmucuy, Mucuychakán, San Agustín Olá, Pich, Alfredo V. Bonfil, Uzahsil Edzná (NohYaxché), Los Laureles, San Miguel de Allende, Nilchí, San Francisco Kobén, Hampolol, Carlos Cano Cruz (Los Tlaxcaltecas), Uayamón, Imí, San Luciano and Pocyaxum.

There are 133 designated temporary shelters for use in emergencies (preschools, primary schools, high schools, televised remote-education schools and other buildings), with a capacity of harboring 13,988 people. 
The affected communities listed above are threatened primarily by tropical cyclones (tropical waves through hurricanes), with the heavy rainfall bringing the risk of recurrent flooding. This flooding generally happens along the coast, because often the storm tide drives sea levels higher and the ocean waters flow inland, flooding large areas of urban land, where inhabitants face material and economic damages and losses. The coastal areas of Campeche have seen a recurrence of such events, and these have been growing in frequency. Between 1735 and 1900 there were only nine hurricanes recorded, while between 1901 and 2019 there were 21. Looking at the periods of time in which the hurricanes occurred shows that after only nine events in 165 years, the frequency has tripled in the past 100 years, in this zone.

\section{EFFECTS OF HYDRO-METEOROLOGICAL RISK}

The problem of flooding is closely related to hydro-meteorological phenomena, although the most direct relationship is between the location of these human settlements and their vulnerability. This refers specifically to the decisions made by inhabitants in choosing a location to build their homes and services: in many cases along river banks, in ravines, hills, and coastal areas, among others. Urbanization can aggravate the impact of more frequent flooding that results from climate change, particularly in the absence of a flood management infrastructure that takes climate change into account [7].

The Gulf of Mexico region, and the communities situated along its shores, are exposed to the effects of uncontrolled and disproportionate growth of urban development along coastlines, together with coastal tourist resorts and over-fishing... gradually encroaching upon and displacing productive activities and means of subsistence that are the basic economic support for the original inhabitants. These ecosystems are subject to a wide range of non-climate stressors as well, including urban and tourist developments and the indirect effects of overfishing.

The hydro-meteorological phenomena present along coastlines can also affect coastal ecosystems, altering the means of survival for human beings; although these situations also encourage the creation of situations, and the means of adoption and adaptation to resist the impact of such extreme conditions on the population.

The main risks identified for the city of Campeche are storm tides and astronomical tides, which are more damaging because of the city's localization on a flat section of geographic terrain, meaning that their effects and consequences fall mainly upon the inhabitants, affecting the city's buildings, and architectural and urban heritage.

Storm tides are also one of the main causes of flooding in coastal zones, because they are directly related to the rise and seasonal change in sea levels when the coastal zone is under the effects of a hurricane. According to studies of Campeche, Los Petenes and the eastern part of the Laguna de Términos record the highest storm tide levels; thus, the highest risk of flooding. This leads us to reflect upon the greater physical and technical risk faced by people living in these zones, and the perceptions of disaster risk held by the inhabitants under constant threat of these natural phenomena [12]. The threat of flooding from storm tides has gradually increased (Fig. 2).

In a five-year period, the sea levels will rise by $89 \mathrm{~cm}$, partially flooding neighborhoods like Colonia Centro, Solidaridad Nacional, and Palmas I, II and II. In another 20 years, researchers say a storm tide of $180 \mathrm{~cm}$ would cause further flooding in Col. Lazareto, Col. San Bartolo, San Román, Col. Centro, Barrio de San Francisco, and Barrio Guadalupe. Meanwhile, Col. 7 de agosto; the Zona pesquera (the fishing zone); Solidaridad Nacional; Palmas I, II, III; Ah Kim Pech and Villas de Ah Kim Pech would be totally under water. 


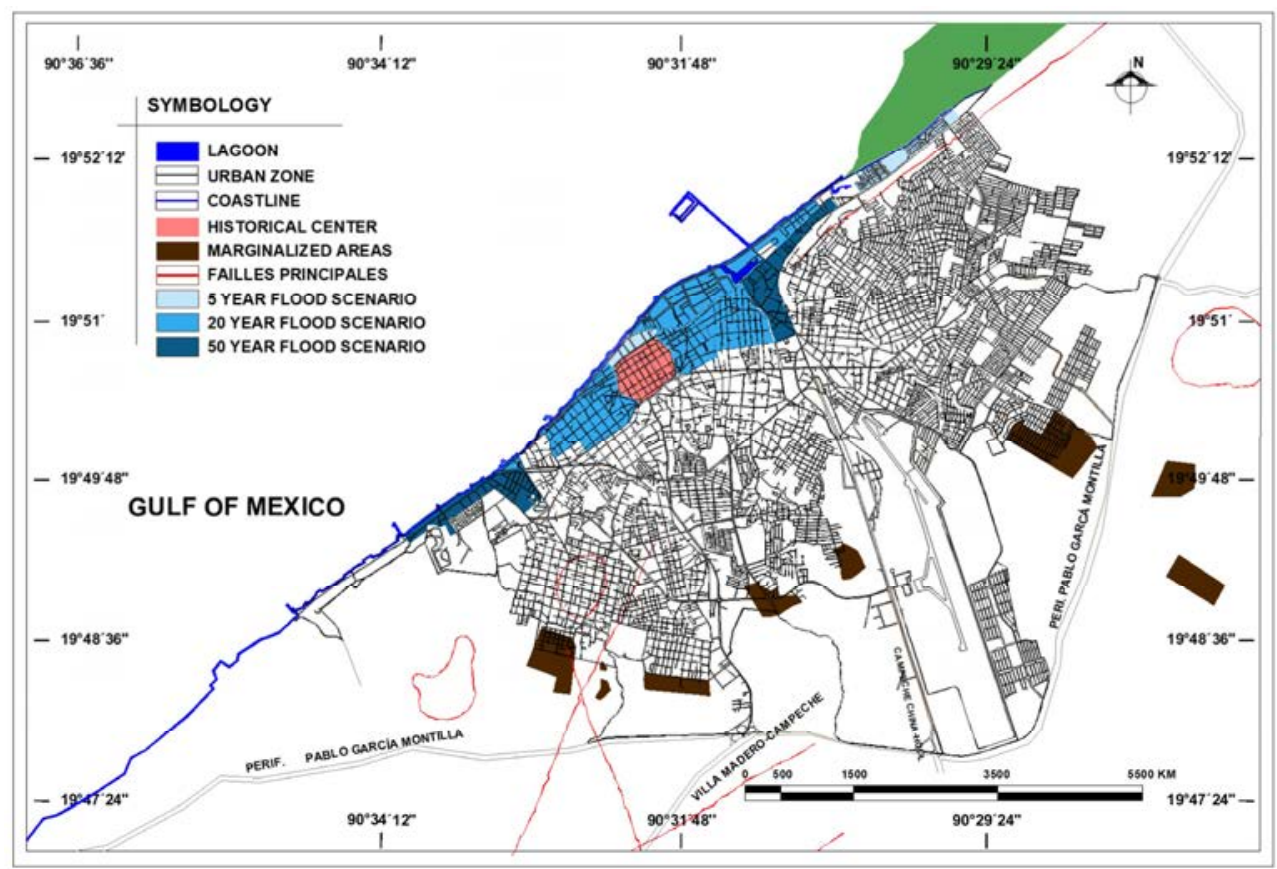

Figure 2: Flood-prone areas of San Francisco de Campeche: 5, 20 and 50-year projections predicted in [1], [4]-[6], [10], [14].

In a scenario encompassing 50 years, a storm tide of $232 \mathrm{~cm}$ can be expected, causing partial flooding in Col. Miramar, Bosques de Campeche, Col. Lazareto, Col. San Bartolo, San Román, Col. Centro, Barrio de San Francisco, Barrio Guadalupe, and Barrio de la Ermita; while Col. 7 de agosto, the Zona Pesquera, Solidaridad Nacional, the Palmas (I, II and III), Ah Kim Pech, and the Villas de Ah Kim Pech would be totally under water.

Another threat facing the population is the sinking and collapse of Karstic terrain, primarily because of the type of soil on which the city is built. The zones of high susceptibility have been identified, where hydro-meteorological events may trigger local manifestations of hazards from sinking or collapse [14]. Although downtown Campeche is only considered at risk of sinking or collapse of Karstic terrain under conditions of moderate dissolution, it is important to take this into account in planning future growth or consolidation of urban zones in the city.

The amount of damage and loss to which the population is exposed will depend on the reaction and response to external events, and the response capacity to tropical storms present in the coastal areas depends in turn on the inhabitants' capacity to remember the periods and intervals within which the phenomenon occurs. This would reduce the risk of disaster and create a way to remain alert and prepared during the season for storms, tropical depressions and storm tides, among others. Yet the marginalized communities established in coastal zones that are at risk of flooding are more vulnerable, because of their economic circumstances (their income, standard of living and economic position), their social condition (exclusion, level of empowerment, social security) and the fact that they normally inhabit the outskirts of the city, where infrastructure and urban facilities are lacking. 
In addition to the above, the evaluation of the risk and vulnerability of the coastal area of Campeche is directly related to two general aspects, the information related to disaster risk reduction at the government level and the information that the population has access to. The communication that the government has at all levels is essential, since it is related to the way the population responds to an emergency.

It was identified that if the work of informing the population with early warnings is carried out in a timely manner, citizens respond better. The systems implemented by the institutions involved; such as civil protection, port captaincy, and the management of social information networks, have been immediate and effective means of gaining information for the majority of the population.

The evaluation of vulnerability was identified from the statistical and geographical analyses that helped document the vulnerability of the tourist city of Campeche. The following were taken as basic indicators: altitude, historical population, population density, historical rainfall, marginalization, temperature, number of inhabitants and housing number, among others. Mainly the urban and social aspects that determine highly vulnerable areas in situations of hydrometeorological risk. For the analysis of information at the local level; however, interviews were conducted aimed at the population, to get to know the perception of the threats they face, understand how they respond and how they adapt to these conditions. The inhabitants affirmed that the climate has a direct relationship with their home, since they feel the impacts of the high temperatures and the floods that can occur.

\section{CONCLUSIONS}

Identifying vulnerable areas of tourist cities that are under threat of hydro-meteorological events can help focus implementation of disaster prevention strategies, to counter hydrometeorological risks. The focus of these efforts should be on the most vulnerable segments of society, whose response capacities are currently minimal; and whose economic, social and physical resources limit their capacity to resume daily life after a disaster.

Based on the information obtained in this study, it can be concluded that the communities that inhabit the coastal zone of the city of Campeche will continue to be at risk from hydrometeorological phenomena; and that their response capacity and resilience will depend on their economic, social and physical circumstances at the time of the emergency. But the way they respond to emergency situations will also depend on the inhabitants' capacity for historic memory, referring to ways to prepare for their physical safety and to preserve their property, and to their ability to learn to identify and recognize the most frequent events, tropical storms and depressions, and the more intense events, like hurricanes. It is through collective memory that communities can recognize events that cause damage where they live; and thus, increase their response capacity and their resilience to hydro-meteorological events that occur in coastal areas. This being the case, authorities at all levels of government can play a strategic role in preventing and reducing the risk of disaster to the population.

Adaptation strategies within the communities are based on the lessons learned from the more elderly members, who have observed natural phenomena like hurricane seasons, and can ensure the transmission from generation to generation of ancestral knowledge on recognizing the weather. It is therefore of crucial importance that an effort be made to encourage the collection and preservation of the inhabitants' historic memory, based on ancestral knowledge of weather, specifically in terms of the detection and prevention of damage from hydro-meteorological phenomena present in the city of Campeche.

Preventive planning for hydro-meteorological phenomena, specifically in government agencies, is fundamental for reducing the risk of disaster in the coastal areas of Campeche. Nationwide civil defense systems have included early alert systems that keep the entire 
population up to date about weather-related emergencies. Response capacity can also be improved on by workshops on early-response training for hydro-meteorological events, open to the general public. The city of Campeche in particular should organize preventive workshops not only for the local inhabitants; but for hotel owners, businesses and tourists, so that all can participate in reducing the risk of disaster.

Proposed actions:

- Preserving the local means of subsistence, in order to reactivate the economy of the historic downtown Campeche.

- Specific training for marginalized communities identified by the government agency, aimed at improving their responses of adaptation and resilience to natural disaster.

- Comprehensive management of appropriate systems for rebuilding homes damaged by flooding, preserving to the extent possible the local homebuilding traditions and knowledge from Campeche state and the surrounding region.

- Comprehensive management of appropriate systems for improving urban facilities and infrastructure damaged by flooding.

- It is crucial to incorporate the use of advanced technology for disaster prevention in coastal areas. Remote sensing technology, modeling, the use of geographic information systems and virtual reality tools all offer clear options for reducing the risk of disaster in these regions.

\section{ACKNOWLEDGEMENTS}

The authors are grateful for the support of the Instituto Politécnico Nacional (National Polytechnical Institute) ESIA TEC in carrying out research project SIP 20195755, and the collaboration of social-service students Miguel Á. Pascual Hernández, Liz Belaunzaran Especie and Arturo Toro Juárez.

\section{REFERENCES}

[1] Instituto Nacional de Estadística y Geografía de México (INEGI), Anuario estadístico y geográfico por entidad federativa 2017 (Annual statistical and geographic data by federal entity, 2017), 2017, http://internet.contenidos.inegi.org.mx/contenidos/ Productos/prod_serv/contenidos/espanol/bvinegi/productos/nueva_estruc/aegef_2017 1702825097929.pdf.

[2] Servicios turísticos por Entidad Federativa 2017 (Tourism services by federal entity for 2017), www.datatur.sectur.gob.mx/SitePages/InventarioTuristico.aspx.

[3] Sistema Nacional de Información Estadística y Geografía de Turismo (National system of statistical information and the geography of tourism) (SNIEGT). www.datatur.sectur.gob.mx/CiudadesPatrimonio/Campeche.aspx.

[4] Comisión Nacional del Agua (National Water Commission), Coordinación General del Servicio meteorológico Nacional (CONAGUA), Subgerencia de pronóstico meteorológico, Base de datos de ciclones tropicales que afectaron a México durante el periodo de 1970 a 2011 (Database on tropical cyclones that affected Mexico during 1970 to 2011), ed. A. Hernández Unzón, 2012.

[5] Centro Nacional de Prevención de Desastres (National Center for Disaster Prevention) (CENAPRED), Declaratorias sobre emergencia, desastre y contingencia climatológica. Datos y Recurso (Declarations on emergencies, disasters, and climatological contingencies. Data and resources), 2017.

https://datos.gob.mx/busca/dataset/declaratorias-sobre-emergencia-desastre-ycontingencia-climatologica. 
[6] National Oceanic and Atmospheric Administration (NOAA), National Hurricane Center and Central Pacific Hurricane Center, 2019.

www.nhc.noaa.gov/data/tcr/index.php?season=2017\&basin=atl.

[7] Intergovernmental Panel on Climate Change (IPCC), Cambio climático 2014: Informe de síntesis. Contribución de los Grupos de trabajo I, II y III al Quinto Informe de Evaluación del Grupo Intergubernamental de Expertos sobre el Cambio Climático (Climate change 2014: Report. Contributions from Working Group I, II, and III to the Fifth Report from the Intergovernmental Group of Experts on Climate Change), eds R.K. Pachauri \& L.A. Meyer, IPCC: Geneva, Suitzerland, p. 157. www.ipcc.ch/site/assets/uploads/2018/02/SYR_AR5_FINAL_full_es.pdf.

[8] Escobar Ohmstede, A., Desastres agrícolas en México. Catálogo histórico II. Siglo XIX (1822-1900) México (Agricultural disasters in Mexico. Historical catalog II. XIX century (1822-1900) Mexico), Fondo de Cultura Económica, CIESAS, 2004.

[9] García Acosta, V., Pérez Zevallos, J.M. \& Molina del Villar, A., Desastres agrícolas en México. Catálogo histórico, I. Época prehispánica y Colonia (Agricultural disasters in Mexico. Historical catalog I. Prehispanic and colonial times) (958-1822), 2018, Fondo de Cultura Económica, CIESAS: México, 2003.

[10] Servicio Meteorológico Nacional (National Weather Service) (CONAGUA), https://smn.cna.gob.mx/es/climatologia/temperaturas-y-lluvias/resumenes-

mensuales-de-temperaturas-y-lluvias.

[11] Banco Interamericano de Desarrollo (National Development Bank) (BID), Campeche Sostenible. Plan de acción. Propuestas para una bahía más limpia, una ciudad más visible, y una administración fuerte y ordenada (Sustainable Campeche. Action Plan. Proposals for a cleaner bay, a more visible city, and a stronger and more organized administration). Gobierno del Estado de Campeche.

www.ccpy.gob.mx/pdf/agenda-campeche/campeche-sostenible-plan-deaccion/CiudadesSustentablesCampechePlanDeAccion2015.pdf.

[12] Posada Vanegas, G. et al., Marea de tormenta (Storm surge). Peligros Naturales en el Estado de Campeche. Cuantificación y Protección Civil (Natural Perils in the State of Campeche. Quantification and Civil Proteccion), eds G. Posada Vanegas, B.E. Vega Serratos \& R. Silva Casarín, Universidad Autónoma del Estado de Campeche, CENECAM- Gobierno del Estado de Campeche, CENAPRED: Campeche, pp. 63-80, 2013.

www.seprocicam.gob.mx/descargas/Peligros $\% 20$ Naturales $\% 20$ en $\% 20$ el $\%$ Estado $\% 2$ 0de\%20Campeche.pdf.

[13] Plan Estatal de Contingencias para Fenómenos Hidrometeorológicos (State Plan for Contingencies in the case of Metereological Phenomena) (PECFH), Gobierno del Estado de Campeche, Centro Estatal de Emergencias: San Francisco de Campeche, México, 2014.

www.proteccioncivil.gob.mx/work/models/ProteccionCivil/swbcalendario_Elemento Seccion/655/PLAN_ESTATAL_CONTINGENCIAS_PARA_FENONEMOS_HIDR OMETEOROLOGICOS_2014.PDF.

[14] Palacio Aponte, A.G. et al., Diagnóstico de Riesgo por Inundación para la Ciudad de Campeche (Diagnostic of the Risk of Flooding for the City of Campeche), Universidad Autónoma de Campeche, H. Ayuntamiento del Municipio de Campeche: Campeche, p. 109, 2005. http://etzna.uacam.mx/epomex/pdf/Inundaciones_Campeche.pdf. 